\author{
Sylwia Grzędzińska ${ }^{1}$, Maciej Ziułkiewicz ${ }^{2}$ \\ (1) Uniwersytet Łódzki, Wydział Nauk Geograficznych, studia II', kierunek Geografia; (2) Uniwersytet Łódzki, Wydział Nauk Geograficznych, Pracownia Geologii \\ E-mail: s.grzedzinska@gmail.com; maciej.ziulkiewicz@geo.uni.lodz.pl
}

Historia artykułu: data wpływu 15.05.2017; data akceptacji 02.10.2017

\title{
Charakterystyki fizykochemiczne wód obszarów podmokłych w granicach aglomeracji warszawskiej na przykładzie Horowego Bagna i Jeziora Kruczek w gminie Marki
}

\section{Physico-chemical characteristics of wetland waters in the range of the Warsaw agglomeration on the example of the Horowe Bagno peat bog and the Kruczek Lake in the Marki commune}

Zarys treści

\begin{abstract}
W celu ograniczenia presji i zachowania środowiska przyrodniczego, w najbliższym zapleczu aglomeracji warszawskiej został utworzony Warszawski Obszar Chronionego Krajobrazu (WOCHK). Obejmuje on m.in. tereny leśne okolic Marek, tworzących otulinę obszarów podlegających ściślejszej ochronie, w tym - rezerwatu Horowe Bagno oraz Jeziora Kruczek. Powierzchnia rezerwatu wynosi blisko 44 ha, z czego powierzchnia akwenów powstałych w zagłębieniach potorfowych wynosi około 17,5 ha. Oba obiekty hydrograficzne, ze względu na położenie, znajdują się w zasięgu potencjalnej presji ze strony północno-wschodniej części miasta Marki oraz biegnącej w granicach rezerwatu drogi krajowej nr 631. Ponadto dużym zagrożeniem wydaje się budowa wylotu drogi ekspresowej $\$ 8$ z Warszawy w kierunku Białegostoku. Niniejsza praca stawia sobie za cel udokumentowanie stanu hydrochemicznego torfowiska Horowe Bagno i Jeziora Kruczek sprzed uruchomienia arterii komunikacyjnej S8. Posłużą do tego celu podstawowe parametry fizykochemiczne wód w obu obiektach: odczyn oraz przewodność elektrolityczna właściwa. Do pomiarów realizowanych w sezonie zimowo-wiosennym 2015/16 wytypowano 6 punktów pomiarowo-kontrolnych, przy czym 2 punkty zlokalizowane były nad brzegiem Jeziora Czarnego, a pozostałe 4 znajdowały się na terenie rezerwatu Horowe Bagno. We wstępnym etapie prac badawczych dokonano identyfikacji wielkości presji antropogenicznej na obszarze gminy Marki przy wykorzystaniu metody autorstwa Nachlik (2006). Stwierdzono, że w zakresie gospodarki wodno-ściekowej nie istnieją istotne zagrożenia dla środowiska wodnego. Uzyskane wyniki wskazują, że torfowisko Horowe Bagno można zaliczyć do wysokich pod względem odczynu wód i przejściowych pod względem PEW. Torfowisko i jezioro reprezentują dwa odmienne obiekty hydrochemiczne, co jest prawdopodobnie spowodowane charakterem zlewni i strukturą alimentacji: różnym udziałem zasilania wodami meteorycznymi i gruntowymi. Jednym istotnym obecnie przejawem antropopresji jest przenikanie ścieków opadowych z drog nr 631. Może się ono istotnie zwiększyć po uruchomieniu przylegającego do torfowiska odcinka S8, zwłaszcza bez podjęcia odpowiednich rozwiązań ochronnych.
\end{abstract}

Słowa kluczowe Torfowiska, cechy hydrochemiczne, aglomeracja warszawska, rezerwat.

Abstract In order to limit the pressure and preserve the natural environment in the immediate vicinity of the Warsaw agglomeration
was created the Warsaw Protected Landscape Area. It includes, among others, forests of the Marki area, forming a buffer zone
of protected areas, including the Horowe Bagno peat bog and the Kruczek Lake. The area of the reserve is nearly 44 hectares,
of which the surface of the basins formed in the peat pits is about 17.5 hectares. Both hydrographic objects, due to their location,
are within the range of potential pressure from the northeastern part of the city of Marki and the national road No. 631 . In addition,
the construction of the expressway $S 8$ from Warsaw towards Biatystok seems to be a big threat. This paper aims to document the
hydrochemical condition of the Horowe Bagno peat bog and the Kruczek Lake before the launch of the S8 express road. The basic
physicochemical parameters of water in both objects: $\mathrm{pH}$ and proper electrolytic conductivity will serve this purpose. For measuring
in the winter-spring season 2015/16, 6 measurement and control points were selected, with 2 points located on the shore of
the Kruczek Lake, and the remaining 4 were located in the Horowe Bagno peat bog reserve. In the preliminary stage of the research,
the size of anthropogenic pressure was identified in the area of the Marki commune using the method by Nachlik (2006). It has been
found that there are no significant threats to the aquatic environment in the water-sewage economy. The results show that the
Horowe Bagno peat can be classified as high in pH and transient in terms of PEW. The peat bog and the lake represent two distinct
hydrochemical objects, probably due to the basin and alimentation and different contribution of atmospheric and land supply. One
of the most important manifestations of anthropopression is the penetration of precipitation wastewater from road No. 631 . It can
significantly increase after launching the S8 express road adjacent the peat bog, in particular without adequate protection measures. Hydrochemical properties, peatbogs, reserve, the Warsaw agglomeration.

\section{Wprowadzenie}

Aglomeracja warszawska wywiera ogromny wpływ na środowisko naturalne w swoim bezpośrednim sąsiedztwie (m.in. Krogulec 2005). W celu ograniczenia presji i zachowania środowiska przyrodniczego dla stworzenia odpowiednich warunków dla rozwoju turystyki i rekreacji w najbliższym zapleczu aglomeracji warszawskiej, dnia 29 sierpnia 1997 roku, rozporządzeniem Wojewody Mazowieckiego został utworzony Warszawski Obszar 
Chronionego Krajobrazu (WOCHK). Obejmuje on tereny leśne, zespoły wydm i obniżeń międzywydmowych, jak również obiekty wodne. W jego skład wchodzi szereg kompleksów leśnych, w tym Puszcza Kampinoska, a także lasy okolic Marek tworzących otulinę obszarów podlegających ściślejszej ochronie, w tym - rezerwatu Horowe Bagno oraz Jeziora Kruczek. Oba obiekty, ze względu na położenie, znajdują się w zasięgu potencjalnej presji ze strony północno-wschodniej części miasta Marki oraz biegnącej w granicach rezerwatu drogi krajowej nr 631. Ponadto dużym zagrożeniem wydaje się budowa wylotu drogi ekspresowej S8 z Warszawy w kierunku Białegostoku na odcinku od projektowanej wschodniej obwodnicy Warszawy (S17) do obwodnicy Radzymina. Droga ta będzie przebiegać w bezpośredniej bliskości zarówno chronionego torfowiska, jak i jeziora. Na zasadach analogii z innymi inwestycjami drogowymi (Ziułkiewicz i in. 2006; Ziułkiewicz 2010; Moniewski 2015) należy się spodziewać czytelnego jej oddziaływania na lokalną hydrosferę. Ścieki opadowe spływające z pasa drogowego mogą bowiem prowadzić znaczne ilości zanieczyszczeń i tym samym stanowić zagrożenie dla naturalnych ekosystemów, do których zaliczamy torfowiska (Wiśniowska-Kielan, Niemiec, Arasimowicz 2013).

Niniejsza praca stawia sobie za cel udokumentowanie stanu hydrochemicznego torfowiska Horowe Bagno i Jeziora Kruczek przed uruchomieniem arterii komunikacyjnej S8. Posłużą do tego celu dwa parametry fizykochemiczne: odczyn $(\mathrm{pH})$ oraz przewodność elektrolityczna właściwa (PEW).

\section{Obszar badań}

Rezerwat Horowe Bagno i Jezioro Kruczek położone są w północno-wschodniej części gminy Marki, w powiecie wołomińskim i województwie mazowieckim. Rezerwat Horowe Bagno został ustanowiony w 1989 roku Zarządzeniem Ministra Leśnictwa i Przemysłu Drzewnego (M.P. Nr 32 z 1988 roku, poz. 292), jako rezerwat typu florystyczno-faunistycznego i torfowiskowego o dużej wartości szaty roślinnej oraz dużych walorach estetycznych i krajobrazowych. Powierzchnia rezerwatu wynosi blisko 44 ha, z czego powierzchnia akwenów powstałych w zagłębieniach potorfowych wynosi około 17,5 ha. Jest to jeden duży zbiornik oraz szereg mniejszych. Na terenie rezerwatu występują liczne zbiorowiska roślinne, m.in. mszary wysokotorfowiskowe, przejściowe zespoły szuwarowe, jeziorka torfowiskowe, brzeziny bagienne, bory wilgotne i świeże z elementami grądu.

Jezioro Kruczek jest zbiornikiem typu poeksploatacyjnego, po wydobyciu iłów wstęgowych (warwowych) na potrzeby miejscowej cegielni (Kondracki 1998). Obecnie ma ono powierzchnię prawie 3 ha, choć w latach 90. zbiornik ten zajmował powierzchnię około 8 ha.

Wszystkie chronione obecnie zbiorniki mają charakter powydobywczy i powstały przez dopływ wód podziemnych, które na terenie gm. Marki występują pod nieciągłą pokrywą glin zwałowych i iłów warwowych. Zwierciadło wód tego poziomu występuje na głębokościach 3-9 m p.p.t. i ma na ogół charakter swobodny (Włostowski, Borkowski 2000). Głębszy horyzont stanowią wody poziomu wykształconego w utworach peryglacjalnych Wysoczyzny Wołomińskiej znajdujące się w więzi hydraulicznej z utworami wodonośnymi osadów piaszczysto-żwirowych interglacjału mazowieckiego. Nawiercane są one na głębokości 15-20 m p.p.t., poniżej spągu gliny zwałowej stadiału maksymalnego zlodowacenia warty.

Stosunkowo płytkie występowanie wód podziemnych sprzyja pojawieniu się w zagłębieniach terenu podmokłości i zatorfień. Na terenie torfowiska Horowe Bagno dominują obszary podmokłe $z$ wodą do 0,5 m p.p.t. Jest to poziom wód zwierciadła swobodnego, związany z poziomem wód w całej dolinie Wisły. Brak, bądź też ograniczona przestrzennie izolacja, sprzyja efektywnemu zasilaniu opadowemu i wiąże się z groźbą przenikania zanieczyszczeń z powierzchni terenu. Głębokie poziomy wodonośne, należące do jednolitej części wód podziemnych (JCWPd) nr 52, znajdują się na głębokościach około $300 \mathrm{~m}$ i nie mają kontaktu z płytkimi horyzontami wodonośnymi. Z tej też przyczyny nie istnieje zagrożenie przeniesienia skutków ich eksploatacji (zdepresjonowania) na torfowisko Horowe Bagno i Jezioro Kruczek (Kuczyńska i in. 2013). Torfowisko i jezioro, wraz z innymi obiektami hydrograficznymi zlewni rzeki Czarnej, nie są objęte kontrolą stanu ekologicznego wód powierzchniowych. Podobnie wody podziemne na tym terenie nie były objęte kontrolą stanu ilościowego i chemicznego (Kuczyńska i in. 2013).

\section{Metody badawcze}

Do identyfikacji podstawowych parametrów fizykochemicznych wód w torfowisku i jeziorze wytypowano 6 punktów pomiarowo-kontrolnych, przy czym 2 punkty zlokalizowane były nad brzegiem Jeziora Czarnego, a pozostałe 4 znajdowały się na terenie rezerwatu Horowe Bagno (ryc. 1). Pierwszy punkt pomiarowo-kontrolny (ppk 1) położony był nad Jeziorem Kruczek w jego północnej części, gdzie dno jeziora ma charakter organiczny, a drugi w jego części południowej, gdzie do brzegów jeziora przylega duża wydma śródlądowa, a dno jest piaszczyste. Trzeci punkt pomiarowo-kontrolny (ppk 3) wyznaczono na terenie Rezerwatu Horowe Bagno w południowym, mniejszym basenie torfowiska, pełniącego obecnie funkcję leśnego zbiornika przeciwpożarowego. Punkt ten jest położony w odległości około $50 \mathrm{~m}$ od drogi krajowej nr 631. Ppk nr 4 ulokowano w dole potorfowym w większym oddaleniu (około $100 \mathrm{~m}$ ) od drogi krajowej 631. Piąty punkt pomiarowo-kontrolny (ppk 5) znajdował się w północnym, większym basenie torfowiska, przy jego brzegu. Szósty punkt pomiarowo-kontrolny (ppk 6) znajdował się pomiędzy torfianką i granicą lasu, w okrajku większego zbiornika poeksploatacyjnego torfowiska Horowe Bagno.

Do oceny stanu fizykochemicznego wód powierzchniowych wybrano dwa parametry, które dzięki łatwości i pewności pomiarów stwarzają duże możliwości badawcze $w$ terenie. PEW jest miernikiem zawartości w wodach mineralnych substancji rozpuszczonych, a odczyn informuje o równowadze kwasowo-zasadowej roztworów wodnych. Obie te miary wydają się zasadne w ocenie warunków hydrochemicznych panujących w obszarze, gdzie występują wydmy porośnięte borami z wykształconymi w zagłębieniach je rozdzielających torfowiskami oraz jeziorkiem poeksploatacyjnym iłów warwowych. Do 


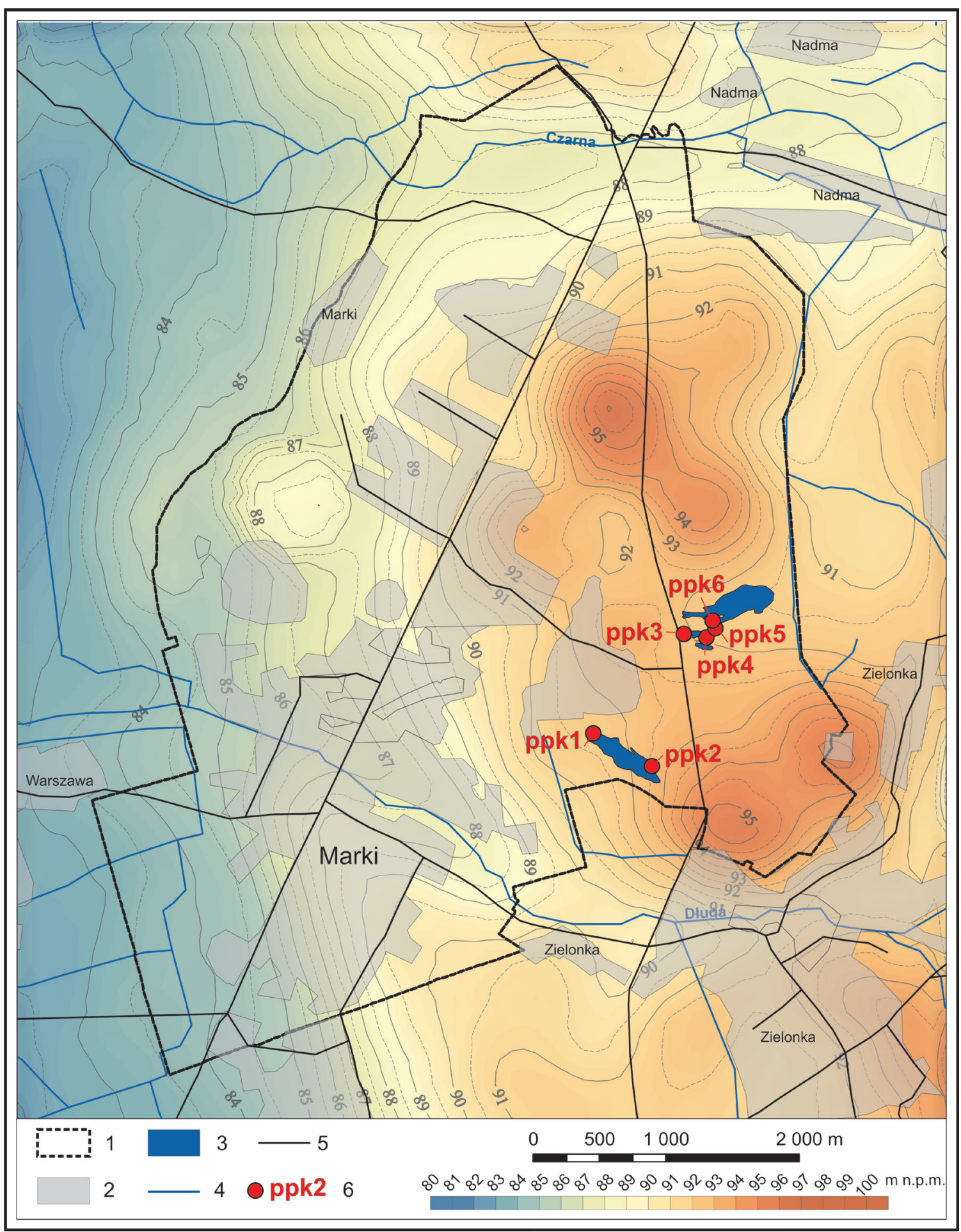

Ryc. 1. Położenie obszaru badań i punktów badawczych w obrębie Jeziora Kruczek (Czarnego) oraz na obszarze torfowiska Horowe Bagno (opr. A. Szmidt na podstawie danych CODGiK udostępnianych bez opłat)

1 - granice gminy Marki, 2 - obszary zabudowane, 3 - zbiorniki wodne, 4 - cieki, 5 - drogi, 6 - punkty pomiarowe

Fig. 1. Location of the research area and research points within the Kruczek Lake (Czarne) and in the Horowe Bagno peat bog (ed. by A. Szmidt based on CODGiK free data)

1 - border of Marki commune, 2 - build-up area, 3 - water reservoirs, 4 - streams of water, 5 - roads, 6 - measurement points

pomiarów zrealizowanych in situ wykorzystano $\mathrm{pH}$-metr cyfrowy CP-215 z elektrodą ESAgP-3015W, kalibrowaną przed wykonaniem badań w roztworach wzorcowych pH 7 i 4 oraz konduktometrem cyfrowym CC-215 z elektrodą EC-60, kalibrowaną przed pomiarami w terenie w roztworze wzorcowym $500 \mu \mathrm{S} / \mathrm{cm}$. Temperaturę wód mierzono termometrem zleniwionym. Zasadnicze badania hydrochemiczne, w wytypowanych punktach, przeprowadzono pięciokrotnie $\mathrm{w}$ sezonie zimowo-wiosennym, w dniach: 05.12.2015 r., 28.12.2015 r., 20.02.2016 r., 02.04.2016 r., 08.05.2016r. 
We wstępnym etapie prac badawczych dokonano identyfikacji wielkości presji antropogenicznej na obszarze gminy Marki, przy wykorzystaniu metody Nachlik (2006). Ze względu na przedmiot zainteresowania ograniczono się do oceny gospodarki wodno-ściekowej, której dokonano na podstawie danych dostępnych na stronie internetowej GUS (2013). Wyniki obliczeń wskaźników przedstawiono w tabeli 1.

Przy dużej gęstości zaludnienia gminy, wysokim zużyciu wody dla potrzeb sieci wodociągowej, ludność obsługi- wana jest w wysokim stopniu przez oczyszczalnie ścieków, dzięki dobrze rozwiniętej infrastrukturze kanalizacyjnej. Powyższe wyniki wskazują, że ścieki oraz odpady stałe nie wydają się stanowić zagrożenia dla jakości wód podziemnych i powierzchniowych na badanym terenie. Ścieki komunalne z terenu gminy są odprowadzane do oczyszczalni ścieków „Czajka” w Warszawie, która odbiera i przetwarza nieczystości z północnych dzielnic lewo- i prawobrzeżnej Warszawy oraz gmin Marki, Ząbki i Zielonka.

Tabela 1. Wskaźniki antropopresji w zakresie gospodarki wodno-ściekowej gminy Marki wg danych GUS (2013) obliczone wg metody Nachlik (2006)

Table 1. Anthropopressure indicators in the area of economy and water and sewage in the Marki commune according to GUS (2013) data calculated according to the Nachik method (2006)

\begin{tabular}{|c|c|c|}
\hline Nazwa wskaźnika & Wartość wskaźnika & Klasa wskaźnika \\
\hline Gęstość zaludnienia & 1124,09 os. $/ \mathrm{km}^{2}$ & bardzo wysoka \\
\hline Zużycie wody na potrzeby sieci wodociągowej & $48,63\left[\mathrm{l} / \mathrm{s} / \mathrm{km}^{2}\right]$ & poza skalą (wartość za wysoka) \\
\hline Ludność obsługiwana przez oczyszczalnie ścieków & $909,79\left[\mathrm{~m}-\mathrm{k} / \mathrm{km}^{2}\right]$ & poza skalą (wartość za wysoka) \\
\hline Ścieki odprowadzane siecią kanalizacyjną & $1,20\left[\mathrm{l} / \mathrm{s} / \mathrm{km}^{2}\right]$ & poza skalą (wartość za wysoka) \\
\hline Odpady komunalne zebrane & 0,67 [tys. ton $/ \mathrm{km}^{2} / \mathrm{rok}$ ] & bardzo wysoka \\
\hline Udział gruntów skomunalizowanych w powierzchni gminy & $46,35 \%$ & bardzo wysoka \\
\hline Udział ludności obsługiwanej przez oczyszczalnie ścieków & $80,93 \%$ & bardzo wysoka \\
\hline
\end{tabular}

Źródło/Source: https://bdl.stat.gov.pl/.

\section{Wyniki}

Wyniki pomiarów parametrów fizykochemicznych zestawiono w tabeli 2. Pod względem wodnych warunków termicznych, największą amplitudę zarejestrowano w północnej części jeziora Kruczek $-17^{\circ} \mathrm{C}$, a najmniejszą w północnym basenie torfowiska $-6,5^{\circ} \mathrm{C}$. Wody w zbiorniku jeziornym były nieznacznie cieplejsze niż na torfowisku.

Odczyn wód powierzchniowych w sezonie zimowo-wiosennym był niski i wskazywał, że badane środowisko wodne jest zakwaszone. Wody jeziora Kruczek miały odczyn nieznacznie wyższy od wód z torfowiska, za wyjątkiem ppk 3 (ryc. 2). Najniższe wartości pH zarejestrowano na początku badań, w okresie późniejszym odczyn się podniósł i do końca obserwacji już tak niskich wartości nie osiągnął. Wody jeziorne cechowały się większym podobieństwem pod względem pH niż wody na torfowisku (ryc. 2), mimo iż ppk 1 i 2 dzieliła większa odległość niż punkty pomiarowe $\mathrm{nr} 3,4$, 5 i 6 (ryc. 1).

Przewodność elektrolityczna właściwa mieściła się w szerokich granicach wartości, od $24,0 \mu \mathrm{S} / \mathrm{cm}$ do $311,0 \mu \mathrm{S} / \mathrm{cm}$ (tab. 2). Generalnie niższe wartości, z zakresu 29,0-70,0 $\mu \mathrm{S} / \mathrm{cm}$ stwierdzono w wodach jeziora, wyższe z przedziału 58,0-311,0 $\mu \mathrm{S} / \mathrm{cm}$ w wodach na torfowisku, przy czym jeden raz, zimą stwierdzono tam PEW na poziomie $24 \mu \mathrm{S} / \mathrm{cm}$. Na uwagę zasługuje utrzymywanie się do lutego 2016 roku podwyższonych wartości PEW w ppk 3 na tle wszystkich pozostałych punktów (ryc. 3). Podobnie jak w przypadku odczynu, tak i pod względem wartości PEW, wody jeziora wykazały się większym podobieństwem wzajemnym niż wody na torfowisku. Wzajemne odniesienie uzyskanych $\mathrm{w}$ pomiarach wartości
PEW i odczynu wód ukazuje czytelną współzmienność, z której wynika, że wraz ze wzrostem pH zmniejsza się przewodność elektrolityczna właściwa wód na torfowisku (ryc. 4). Brak jest natomiast takiej współzmienności w wynikach pomiarów wód jeziornych.

Dla potwierdzenia istnienia zaznaczającej się odmienności wód jeziora Kruczek i wód torfowiska Horowe Bagno, wykonano testowanie statystyczne nieparametryczne testem U Manna-Whitneya (ang. Mann-Whitney $U$ test) zbioru danych hydrochemicznych. Test ten służy do weryfikacji hipotezy o nieistotności różnic pomiędzy medianami badanej zmiennej w dwóch populacjach (przy czym zakładamy, że rozkłady zmiennej są sobie bliskie) (Durka 2003).

$$
\begin{aligned}
& H_{0}: \theta_{1}=\theta_{2}, \\
& H_{1}: \theta_{1} \neq \theta_{2},
\end{aligned}
$$

jeżeli $p \leq \alpha \rightarrow$ odrzucamy $H_{\mathrm{o}}$ przyjmując $H_{1}$ jeżeli $p>\alpha \rightarrow$ nie ma podstaw, aby odrzucić $H_{0}$.

$$
\begin{gathered}
U=n_{1} n_{2}+\frac{n_{1}\left(n_{1}+1\right)}{2}-R_{1} \\
U^{\prime}=n_{1} n_{2}+\frac{n_{2}\left(n_{2}+1\right)}{2}-R_{2} \\
Z=\frac{U-\frac{n_{1} n_{2}}{2}}{\sqrt{\frac{n_{1} n_{2}\left(n_{1}+n_{2}+1\right)}{12}-\frac{n_{1} n_{2} \sum\left(t^{3}-t\right)}{12\left(n_{1}+n_{2}\right)\left(n_{1}+n_{2}-1\right)}}}
\end{gathered}
$$




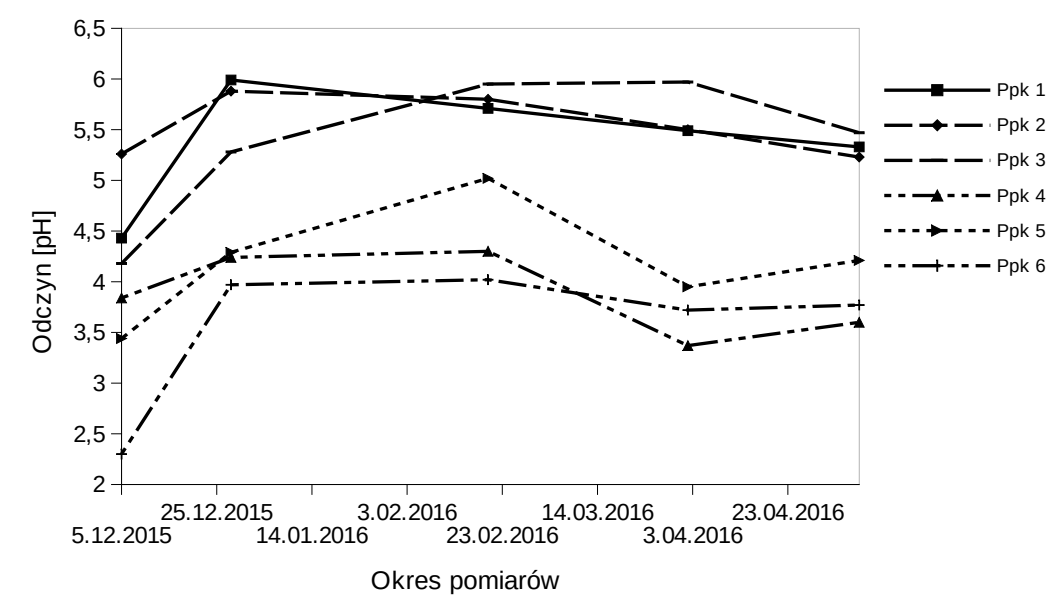

Ryc. 2. Wartości pH w punktach pomiarowo-kontrolnych w obrębie Jeziora Czarnego (ppk 1-2) i na terenie torfowiska Horowe Bagno (ppk 3-6) zimą i wiosną 2015-2016 (opr. własne)

Fig. 2. $\mathrm{PH}$ values at measurement and control points located within the Black Lake (ppk 1-2) and in the Horowe Bagno peat bog (ppk 3-6) in the winter and spring of 2015-2016 (own compilation)

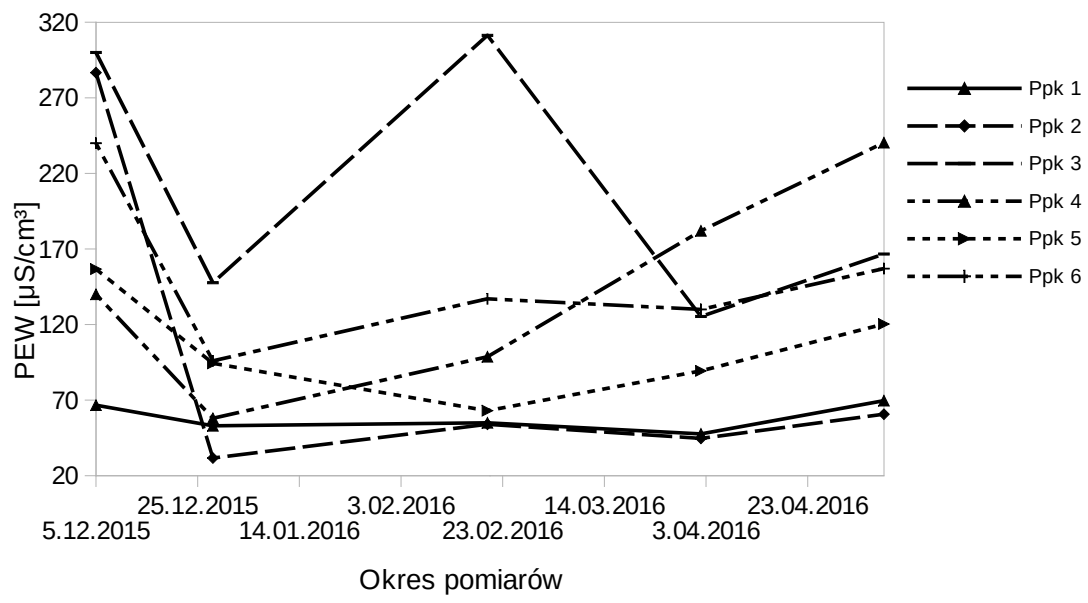

Ryc. 3. Wartości PEW w punktach pomiarowo-kontrolnych w obrębie Jeziora Czarnego (ppk 1-2) i na terenie torfowiska Horowe Bagno (ppk 3-6) zimą i wiosną 2015-2016 (opr. własne)

Fig. 3. PEW values at measurement and control points located within the Black Lake (ppk 1-2) and in the Horowe Bagno peat bog (ppk 3-6) in the winter and spring of 2015-2016 (own compilation)

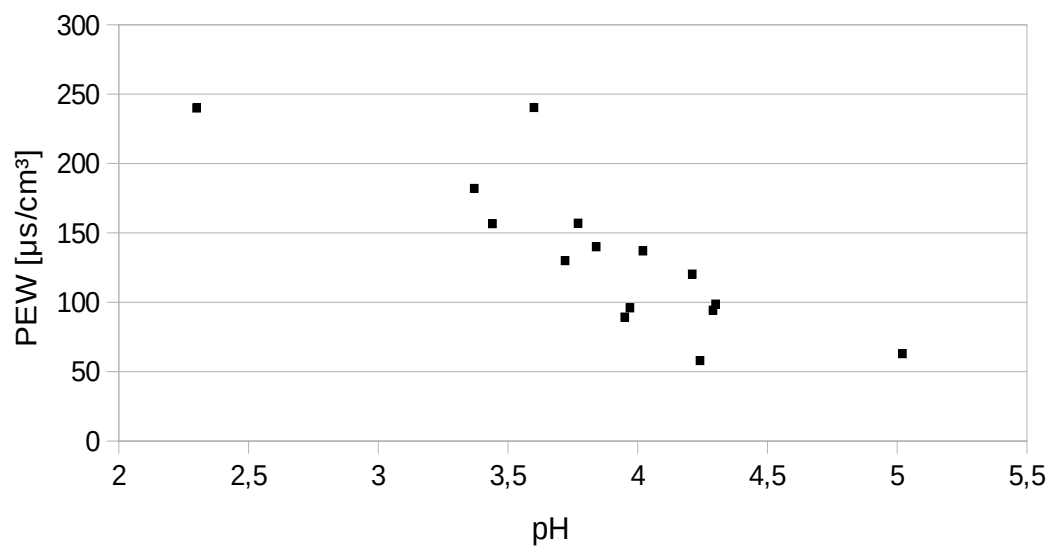

Ryc. 4. Zależność między PEW a pH w punktach pomiarowo-kontrolnych na terenie torfowiska Horowe Bagno (oprac. własne)

Fig. 4. Relationship between $\mathrm{PEW}$ and $\mathrm{pH}$ in measurement and control points located in the Horowe Bagno peat bog (own compilation) 
Tabela 2. Wyniki pomiarów podstawowych parametrów fizykochemicznych wody w Jeziorze Kruczek (Czarnym) oraz torfowisku Horowe Bagno, zima i wiosna 2015/2016 r.

Table 2. Results of measurements of basic physicochemical parameters of water in the Kruczek Lake (Black) and the Horowe Bagno peat bog during testing in the winter and spring of 2015/2016

\begin{tabular}{|c|c|c|c|c|}
\hline $\begin{array}{l}\text { Punkt pomiarowo- } \\
\text {-kontrolny }\end{array}$ & Data pomiarów & Temperatura $\left[{ }^{\circ} \mathrm{C}\right]$ & $\mathrm{pH}[-]$ & $\mathrm{PEW}[\mu \mathrm{S} / \mathrm{cm}]$ \\
\hline \multirow{5}{*}{ Ppk 1} & 05-12-2015 & 3,0 & 4,43 & 67 \\
\hline & $28-12-2015$ & 7,0 & 5,99 & 53 \\
\hline & $20-02-2016$ & 3,4 & 5,71 & 55 \\
\hline & 02-04-2016 & 9,0 & 5,49 & 48 \\
\hline & 08-05-2016 & 20,0 & 5,33 & 70 \\
\hline \multirow{5}{*}{ Ppk 2} & 05-12-2015 & 4,0 & 5,26 & 29 \\
\hline & $28-12-2015$ & 6,2 & 5,88 & 32 \\
\hline & $20-02-2016$ & 3,6 & 5,80 & 54 \\
\hline & 02-04-2016 & 9,4 & 5,50 & 45 \\
\hline & 08-05-2016 & 17,0 & 5,23 & 61 \\
\hline \multirow{5}{*}{ Ppk 3} & 05-12-2015 & 1,0 & 4,18 & 300 \\
\hline & 28-12-2015 & 6,2 & 5,28 & 148 \\
\hline & 20-02-2016 & 2,6 & 5,95 & 311 \\
\hline & 02-04-2016 & 5,2 & 5,97 & 125 \\
\hline & 08-05-2016 & 13,0 & 5,47 & 167 \\
\hline \multirow{5}{*}{ Ppk 4} & 05-12-2015 & 4,0 & 3,84 & 140 \\
\hline & $28-12-2015$ & 6,2 & 4,24 & 58 \\
\hline & 20-02-2016 & 3,0 & 4,30 & 99 \\
\hline & 02-04-2016 & 3,2 & 3,37 & 182 \\
\hline & 08-05-2016 & 15,0 & 3,60 & 240 \\
\hline \multirow{5}{*}{ Ppk 5} & 05-12-2015 & 1,0 & 3,44 & 157 \\
\hline & 28-12-2015 & 6,2 & 4,29 & 94 \\
\hline & $20-02-2016$ & 0,6 & 5,02 & 63 \\
\hline & 02-04-2016 & 1,8 & 3,95 & 89 \\
\hline & 08-05-2016 & 7,5 & 4,21 & 120 \\
\hline \multirow{5}{*}{ Ppk 6} & $05-12-2015$ & 1,0 & 2,30 & 24 \\
\hline & $28-12-2015$ & 6,2 & 3,97 & 96 \\
\hline & $20-02-2016$ & 1,4 & 4,02 & 137 \\
\hline & 02-04-2016 & 1,8 & 3,72 & 130 \\
\hline & 08-05-2016 & 13,0 & 3,77 & 157 \\
\hline
\end{tabular}

Źródło: opr. własne.

Source: own compilation.

Uzyskane wyniki obliczeń testu U Manna-Whitneya ukazują, że istnieją ważne statystycznie różnice w pH pomiędzy wodami torfowiska Horowe Bagno i jeziora Kruczek. Odczyn wód torfowych jest istotnie niższy od pH wód jeziora (średnia rang $\mathrm{pH}$ wód torfowych wyniosła 11,8 i jest znacznie niższa niż pH wód jeziora). Mediana $\mathrm{pH}$ wód torfowych wyniosła 4,1 , natomiast mediana
pH wód jeziora wyniosła 5,5 (ryc. 5). Asymptotyczna wartość prawdopodobieństwa testu obliczona dla poziomu istotności $\alpha=0,05$ wyniosła 0,001233. Hipotezę zerową, że nie ma różnic w odczynie wód z obu typów badanych obiektów należy więc odrzucić.

Podobnie przedstawiają się wyniki testu U Manna-Whitneya w przypadku analizy zbiorów wartości PEW. 


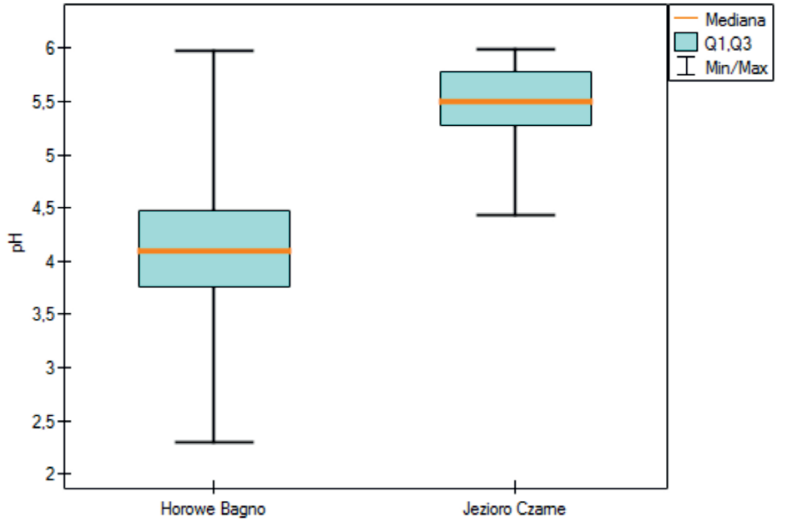

Ryc. 5. Analiza statystyczna U Manna-Whitney’a dla pH wód torfowiska Horowe Bagno i wód Jeziora Czarnego (opr. S. Grzędzińska, 2016)

Fig. 5. The Mann-Whitney $U$ test for the $\mathrm{pH}$ of the Horowe Bagno peat bog water and the Black Lake water (ed. by S. Grzędzińska, 2016)

Na podstawie przyjętego poziomu $\alpha=0,05$ i statystyki Z testu Manna-Whitneya z poprawką na ciągłość $p=0,000764$, jak też na podstawie dokładnej statystyki $U(p=0,000325)$ możemy przyjąć, że istnieją ważne statystycznie różnice w PEW wód torfowych i PEW wód jeziora. Wody torfowiska Horowe Bagno mają wyższe wartości PEW niż wody Jeziora Czarnego (średnia rang dla PEW wód torfowych wyniosła 19,35 (mediana = 138,5) i jest znacznie wyższa niż średnia rang dla PEW wód jeziora, która wynosi 7,8 (mediana $=54,5$ ) - ryc. 6 . Tak samo jak w przypadku $\mathrm{pH}$, hipotezę zerową, że nie ma różnic w PEW obu badanych siedlisk należy odrzucić.

\section{Podsumowanie i dyskusja}

Uzyskane wyniki pomiarów odczynu i przewodności elektrolitycznej właściwej wód pozwalają stwierdzić, że $w$ bezpośrednim sąsiedztwie silnie zurbanizowanych terenów gminy Marki zachowały się obiekty hydrograficzne o niskim stopniu przeobrażenia hydrochemicznego. Jezioro Kruczek, którego wody cechują się niską przewodnością i względnie podwyższonym odczynem, wskazują na możliwość retencjonowania wód opadowych, zatężonych ewaporacyjnie (Małecki 1998; Ziułkiewicz, Fortuniak 2016) o odczynie lekko zalkalizowanym - charakterystycznym dla wód opadowych z obszarów miast (Ziułkiewicz 2003). Wynika z tego, że zagłębienie poeksploatacyjne, w którym wtórnie wytworzył się zbiornik jest szczelne i nie przenikają do niego wody z horyzontów wgłębnych. Mogłyby to potwierdzić szczegółowe badania składu chemicznego wód. Drugie środowisko, czyli torfowisko Horowe Bagno, którego wody cechują się generalnie większą zmiennością czasową i przestrzenną od wód jeziornych, wykazują niższy odczyn i wyższy poziom PEW. Może to wskazywać na istnienie zasilania podziemnego i zakwaszenia wód kwasami organicznymi, uwalnianymi z osadów torfowych. Czynnikiem zakwaszającym wody jest koncentracja jonów wodorowych, będąca wynikiem bilansu reakcji produkujących kwasy i procesów je konsumujących. Do najważniejszych reakcji uwalniających jony wodorowe zaliczamy dysocjację kwasów organicznych/humusowych oraz dysocjację kwasu węglowego (McLaughlin, Webster 2010).

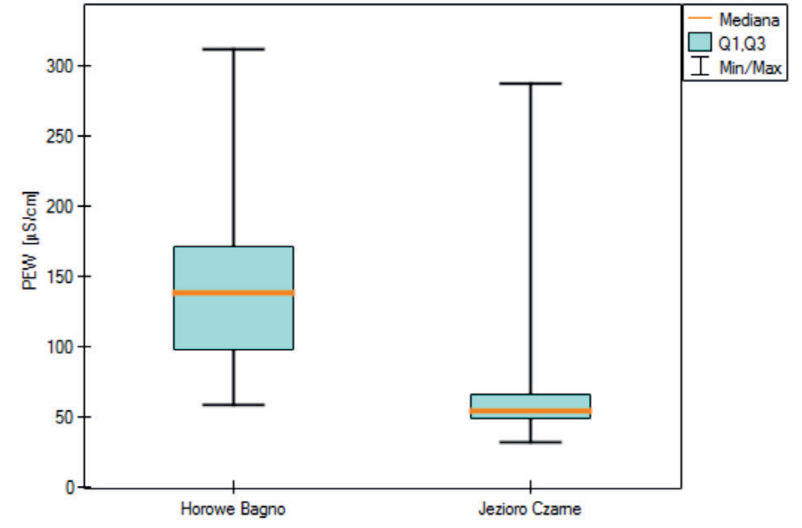

Ryc. 6. Analiza statystyczna U Manna-Whitney'a dla PEW j.w. (opr. S. Grzędzińska, 2016)

Fig. 6. The Mann-Whitney $U$ test for PEW as above (ed. by S. Grzędzińska, 2016)

Wartości PEW wskazują, że torfowisko Horowe Bagno należy zaliczyć do torfowisk przejściowych: przejściowych - topogenicznych (PEW w zakresie 40-120 $\mu \mathrm{S} / \mathrm{cm}$ ) oraz przejściowo-mechowiskowych (PEW w zakresie 300 -500/600 $\mu \mathrm{S} / \mathrm{cm}$ ) (Kujawa-Pawlaczyk, Pawlaczyk 2005). Z uzyskanych pomiarów wynika również, że badane torfowisko kwalifikuje się do torfowisk wysokich, gdyż wartości pH w większości przypadków są niższe od 4,2 (Siegel i in. 2006) (tab. 3). Należy przy tym zwrócić uwagę, że zlewnie bezpośrednie obu badanych obiektów stanowią pola piasków wydmowych porośniętych borem sosnowym. Jest to środowisko sprzyjające zakwaszeniu wód i odwapnieniu podłoża, poprzez które infiltrują agresywne wody opadowe.

Tabela 3. Podział torfowisk na podstawie ich cech chemicznych

Table 3. Classification of peat bogs based on their chemical characteristics

\begin{tabular}{lccc}
\hline \multicolumn{1}{c}{ Nazwa } & $\mathrm{pH}$ & $\begin{array}{c}\text { Alkaliczność } \\
{[\mu \mathrm{eg} / \mathrm{l}]}\end{array}$ & $<\mathrm{Ca}[\mathrm{mg} / \mathrm{l}]$ \\
\hline Wysokie & $<4,2$ & - & $<20$ \\
\hline Przejściowe & $4,2-4,8$ & 0,31 & $2,0-5,5$ \\
\hline Niskie & $5,2-6,8$ & $23-80$ & $6,0-20,0$ \\
\hline Niskie (zasobne) & $6,8-8,0$ & $104-181$ & $>20,0$ \\
\hline
\end{tabular}

Źródło/Source: Ziułkiewicz, Fortuniak 2016.

Wartości przewodności elektrolitycznej właściwej (PEW) (ryc. 3) na początku okresu pomiarowego były wysokie, potem gwałtownie zmalały i po pewnym czasie zaczęły sukcesywnie rosnąć, by ponownie osiągnąć wartości wysokie. Zimą PEW wód torfowych było wysokie, lecz na skutek dostawy wody z roztopów uległo obniżeniu. Wody w obrębie torfowiska (ppk 3-6) charakteryzują się o wiele wyższą przewodnością elektrolityczną niż wody Jeziora Czarnego (ppk 1-2). W małych rzekach leśnych wartość przewodnictwa elektrolitycznego kształtuje się w przedziale 280-485 $\mathrm{\mu S} / \mathrm{cm}$ (Chomutowska, Wilamowski 2012), natomiast w silnie zanieczyszczonych wodach małych cieków miejskich wartości PEW mogą dochodzić nawet do 1000-1 $200 \mu \mathrm{S} / \mathrm{cm}$ (Bojakowska i in. 2012; Ziułkiewicz i in. 2016). Przesłanki do uznania 
presji antropogenicznej wystąpiły w przypadku jednego z punktów badawczych na torfowisku, ppk nr 3, położonego w pobliżu drogi krajowej $\mathrm{nr}$ 631. Zarejestrowano tam najwyższe wartości PEW, znacznie przekraczające maksymalne wyniki w innych częściach torfowiska. Może to wskazywać, zważywszy na okres badań, na dopływ ścieków opadowych z rozpuszczoną solą drogową. Jako sól drogową określamy mieszaninę chlorku sodu $(97 \% \mathrm{NaCl})$, chlorku wapnia $\left(2,5 \% \mathrm{CaCl}_{2}\right)$ oraz heksacyjanożelazianu potasu $\left(0,5 \% \mathrm{~K}_{4}\left[\mathrm{Fe}(\mathrm{CN})_{6}\right]\right)$. Dodatek heksacyjanożelazianu potasu stosowany jest w celu uniknięcia zbrylania się soli, które jest naturalnym zjawiskiem związanym z małą higroskopijnością NaCl (Mazur 2015). Stwierdzono, że stężenie soli w małych ciekach wodnych zależy od ich odległości względem drogi. Stężenie $\mathrm{NaCl}$ w rowach przydrożnych w czasie wiosennych roztopów może osiągać wartość nawet 18000 mg/l. Z kolei w strumieniach znajdujących się dalej od jezdni jego zawartość może dochodzić do $4300 \mathrm{mg} / \mathrm{l}$ (Mahrosh i in. 2014). Problem zasolenia obejmuje również mokradła, stawy oraz glebę. Stężenie soli w mokradłach może dochodzić do $4500 \mathrm{mg} / \mathrm{l}$, a w stawach do $4000 \mathrm{mg} / \mathrm{l}$ (Sanzo, Hecnar 2006). Wysokie stężenia chlorków stają się niekiedy przyczyną zakwaszenia gleby, co wiąże się z obniżeniem aktywności mikrobiologicznej. W wyniku tego hamowane są procesy przemiany związków azotu w glebie oraz rozkładu związków organicznych (Mazur 2015). Prawidłowo funkcjonujący system odwadniania ciągów komunikacyjnych o dużym natężeniu ruchu powoduje, że degradacja środowiska ograniczona jest tylko do pasa terenu bezpośrednio do niego przylegającego, jednak podczyszczanie ścieków drogowych w rowach odwadniających będzie mało skuteczne w przypadku wystąpienia surowych zim, kiedy zostają użyte duże ilości soli chlorkowych (Moniewski, Tomalski 2008). Budowa północnego wylotu z Warszawy drogi ekspresowej S8 w kierunku Białegostoku, na odcinku od projektowanej wschodniej obwodnicy Warszawy (S17) do obwodnicy Radzymina, może jeszcze wywołać silniejsze zmiany właściwości wody w torfowisku oraz jeziorze niż obecnie czyni to droga krajowa nr 631. Na obszarze odcinka drogi ekspresowej S8 brak jest bowiem izolacji pierwszego poziomu wodonośnego, co nakłada konieczność wykonania na tym odcinku zabezpieczeń przed infiltracją zanieczyszczeń z drogi i obiektów towarzyszących. Należą do nich: uszczelnione rowy odprowadzające wody opadowe i roztopowe, uszczelnione stawy retencyjne dla wód odprowadzanych z powierzchni drogi, wyposażone w różnego typu łapacze zanieczyszczeń, zabezpieczenia punktów zrzutu wód spływających z drogi do wód powierzchniowych, zabezpieczenia przed infiltracją zanieczyszczeń z punktów infrastruktury związanej z obsługą i zapleczem technicznym. Należy również przewidzieć zabezpieczenia chroniące wody podziemne oraz torfowe przed infiltracją zanieczyszczeń, które mogą pojawić się w sytuacjach awaryjnych (Mikołajków 2005).

\section{Wnioski}

- Wskaźniki presji środowiskowej gminy Marki wskazują, że środowisko obu badanych obiektów jest wolne od zagrożeń ze strony gospodarki wodno-ściekowej.
Istotne zagrożenie generowane jest natomiast przez już funkcjonującą i przyszłą infrastrukturę komunikacji drogowej.

- Wyniki pomiarów pH wskazują, że badane torfowisko można zakwalifikować do torfowisk wysokich, gdyż wartość pH w większości przypadków są mniejsze niż 4,2 (tab. 2). Wartości PEW wskazują, że niski odczyn nie jest spowodowany kwasami organicznymi.

- Mineralizacja wód wyrażona ich przewodnością elektrolityczną właściwą (PEW) wskazuje, że badane torfowisko należy zaliczyć do torfowisk przejściowych: przejściowo-topogenicznych (PEW w zakresie 40-120 $\mathrm{\mu S} / \mathrm{cm}$ ) oraz przejściowo-mechowiskowych (PEW w zakresie 300-500/600 $\mu \mathrm{S} / \mathrm{cm}$ ).

- Mimo że zlewnie bezpośrednie torfowiska Horowe Bagno i Jeziora Czarnego są pod względem zagospodarowania do siebie podobne, to obiekty wykazują dużą odmienność hydrochemiczną. Jest to prawdopodobnie spowodowane ich genezą oraz strukturą alimentacji.

- Aby ograniczyć dalszą degradację środowiska należy wykonać na planowanym odcinku trasy S8 szereg zabezpieczeń przed infiltracją zanieczyszczeń z drogi oraz obiektów towarzyszących.

\section{Literatura}

Bojakowska, I., Lech, D., Jaroszyńska, J., 2012. Metale ciężkie w osadach Potoku Służewieckiego w Warszawie (Polska). Górnictwo i Geologia 7 (2), 71-83.

Chomutowska, H., Wilamowski, K., 2012. Badania stanu fizykochemicznego wód na terenie Puszczy Białowieskiej. Ochrona Środowiska i Zasobów Naturalnych 54, 190-199.

Durka, P.J., 2003. Testy nieparametryczne, [w:] Durka, P.J., Wstęp do współczesnej statystyki. Wydawnictwo Adamantan, Warszawa, 1-104.

Kondracki, J., 1998. Geografia regionalna Polski. Wydawnictwo Naukowe PWN, Warszawa, 1-440.

Krogulec, E., Mikołajków, J., Jóźwiak, K., 2005. Badania monitoringowe wód podziemnych obszarów chronionych o różnym poziomie antropopresji. Przegląd Geologiczny 53 (6), 522-526.

Kuczyńska, A., Palak-Mazur, D., Cabalska, J., Galczyk, M., Kucharczyk, K., Kostka, A., Mikołajczyk, A., Stojek, M., Rojek, A., Solovey, T., 2013. Raport o stanie chemicznym oraz ilościowym jednolitych części wód podziemnych w dorzeczach w podziale na 161 i 172 JCWPd, stan na rok 2012. PIG-PIB, Warszawa.

Kujawa-Pawlaczyk, J., Pawlaczyk, P., 2005. Ochrona mokradeł, [w:] Gwiazdowicz, D. (red.), Ochrona przyrody w lasach, t. II: Ochrona szaty roślinnej. Wydawnictwo ORNATUS, Poznań, 81-119.

Mahrosh, U., Kleiven, M., Meland, S., Rosseland, B.O., Salbu, B., Teien, H.C., 2014. Toxicity of road deicing salt ( $\mathrm{NaCl}$ ) and copper (Cu) to fertilization and early developmental stages of Atlantic salmon (Salmo salar). Journal of Hazardous Materials 280, 331-339.

Małecki, J.J., 1998. Rola strefy areacji w kształtowaniu składu chemicznego płytkich wód podziemnych wybranych środowisk hydrochemicznych. Biuletyn Państwowego Instytutu Geologicznego 381, $1-219$.

Mazur, N., 2015. Wpływ soli do odladzania dróg na środowisko przyrodnicze. Inżynieria i Ochrona Środowiska 18 (4), 449-458.

McLaughlin, J.W., Webster, K.L., 2010. Alkalinity and acidity cycling and fluxes in an intermediate fen peatland in northern Ontario. Biogeochemistry 99 (1), 143-155.

Mikołajków, J., 2005. Planowanie inwestycji drogowych w aspekcie zagrożenia dla wód podziemnych na przykładzie autostrady A2. Przegląd Geologiczny 56 (7), 586-590.

Moniewski, P., 2015. Cechy fizykochemiczne wód powierzchniowych i ich sezonowa zmienność na przykładzie Dzierżąznej. Acta Scientiarum Polonorum Formatio Circumectus 14 (3), 93-106. 
Moniewski, P., Tomalski, P., 2008. Wpływ systemu odwodnienia auto strady na ilość i jakość wody małej rzeki, [w:] Patryka, J., Pociask-Karteczka, J. (red.), Wody na obszarach chronionych. Instytut Geografii i Gospodarki Przestrzennej UJ. Ojcowski Park Narodowy. Komisja Hydrologiczna PTG, Kraków, 237-246.

Monitor Polski, 1988. Zarządzenie Ministra Ochrony Środowiska i Zasobów Naturalnych w sprawie uznania za rezerwaty przyrody 32, poz. 292.

Nachlik, E. (red.), 2006. Identyfikacja i ocena skutków antropogenicznych oddziaływań na zasoby wodne dla wskazania części wód zagrożonych nie osiągnięciem celów środowiskowych. Politechnika Krakowska, Kraków, 1-318.

Sanzo, D., Hecnar, S.J., 2006. Effects of road de-icing salt $(\mathrm{NaCl})$ on larval woods frogs (Rana sylvarica). Environmental Pollution 140, 247-256.

Siegel, D.I., Glaser, P.H., So, J., Janecky, D.R., 2006. The dynamic balance between organic acids and circumneutral groundwater in a large boreal peat basin. Journal of Hydrology 320, 421-431.

Wiśniowska-Kielan, B., Niemiec, M., Arasimowicz, M., 2013. Przydrożne zbiorniki ścieków opadowych jako element ochrony jakości wód. Inżynieria Ekologiczna 34, 62-75.

Włostowski, J., Borkowski, P., 2000. Mapa Hydrogeologiczna Polsk w skali 1:50 000488 Radzymin. Państwowy Instytut Geologiczny.
Włostowski, J., Borkowski, P., 2000. Objaśnienia do Mapy Hydrogeologicznej Polski w skali 1:50 000488 Radzymin. Państwowy Instytut Geologiczny.

Ziułkiewicz, M., 2003. Zmienność chemizmu wód podziemnych na obszarze Łodzi. Przegląd Geologiczny 51 (4), 327-336.

Ziułkiewicz, M., 2010. Chemizm wód gruntowych na obszarze drenażu źródliskowego, [w:] Ziułkiewicz, M. (red.), Stan i antropogeniczne zmiany jakości wód w Polsce, tom 6. Wydawnictwo Uniwersytetu Łódzkiego, Łódź, 88-107.

Ziułkiewicz, M., Fortuniak, A., 2016. Hydrochemical zoning of valley peatland as a result of water supply conditions: examples from Poland. Geology, Geophysics and Environment 42 (1), 39-53.

Ziułkiewicz, M., Fortuniak, A., Górecki, M., Grzędzińska, S., Małecka, B., Waack-Zając, A., 2016. Zdjęcie hydrochemiczne rzeki miejskiej na przykładzie Olechówki. Monografie Komitetu Gospodarki Wodnej PAN 39, 279-291.

Ziułkiewicz, M., Hereźniak, J., Hereźniak-Ciotowa, U., Burchard, J., 2006. Hydrochemiczna charakterystyka wód źródlanych zlewni Dzierżąznej, [w:] Burchard, J., Ziułkiewicz, M. (red.), Stan i antropogeniczne zmiany jakości wód w Polsce, tom 4: Jakość wód zlewni Dzierżąznej. Wydawnictwo Uniwersytetu Łódzkiego, Łódź, 85-100.

Żurek, S., 2006. Katalog rezerwatów przyrody na torfowiskach Polski. Wydawnictwo Akademii Świętokrzyskiej, Kielce, 1-288. 